\title{
Misconceptions of mangrove ecology and their implications on conservation and management
}

\author{
Mala D. Amarasinghe \\ Department of Botany, University of Kelaniya, Kelaniya 11600, Sri Lanka \\ Correspondence (mala@kln.ac.lk) \\ https://orcid/org/0000-0001-8206-9260
}

\begin{abstract}
Being uniquely located in the harsh inter-tidal zone between land and sea, mangroves have long been considered mosquito-infested stinky and muddy environments, that can be made worthy only through "development" and converted to land suitable for other lucrative land uses such as coconut cultivation, homestead/ urban/ tourism related infrastructure development. Mangrove ecological research initiated in Florida in the late 60's gave an insight over their ecological value and their potential positive influence on fisheries (secondary productivity) of estuaries and coastal waters through nutrient cycling. Apart from taxonomic and biogeographic studies, considerable research effort has since been devoted globally that has elucidated the nature of ecological functions of mangrove ecosystems ranging from primary productivity and carbon sequestration to nutrient cycling and maintenance of coastal biodiversity that has generated an invaluable knowledge base useful to draw up sustainable plans to conserve mangroves which are under heavy anthropogenic pressure. A few misconceptions however are often encountered with regard to characterization of mangrove habitats and species exclusive to them that inflict far-reaching negative impacts on mangrove conservation. This paper analyses them with the available scientific knowledge base and identifies the potential driving forces that contribute to pseudo-science that leads to eventual loss of mangroves and their invaluable ecological functions.
\end{abstract}

Keywords: inter-tidal zone; mangrove associates; tropical estuaries; true mangroves

\section{INTRODUCTION}

Land-sea interface is a unique habitat as its not only influenced by terrestrial environmental factors but also by oceanic conditions, especially the tides. Inter-tidal zones of the coasts are characterized by highly variable environmental factors, such as temperature, sedimentation and tidal currents (Nagelkerken et al. 2008) and therefore are marginally conducive for plant life, particularly of flowering plants, due to lack of freshwater, unstable anoxic soils and unfavourable conditions for reproduction. Angiosperms that have special abilities to circumvent these adversaries are the natural colonizers of these harsh habitats. In the tropics and sub-tropics, taxonomically unrelated group of flowering plants endowed with morphological adaptations such as pneumatophores, stilt, prop, knee and buttress roots, called mangroves, are able not only to survive in anaerobic soils but also are capable of supporting themselves to stay upright on the unstable substratum characteristic to the inter-tidal zone. The physiological adaptations that provide these plants to maintain osmotic potentials conducive to absorb freshwater from saline soils and adaptations to conserve freshwater within the plant, along with viviparous seed production have enabled them to survive and perform well in this harsh inter-tidal environment. High primary productivity of mangroves (Bouillon et al. 2008) is strong evidence for the effectiveness of the above adaptations of these species to the intertidal zone. Exclusivity represents therefore, the extent to which these species are adapted to the inter-tidal environment and able to perform ecological functions in this harsh environment.

Ecological functions of mangroves were first brought into attention with the research carried out in mangrove areas in Florida bay, USA in the late 1960s and 70's to determine the potential contribution of mangroves to fishery production (Odum and Heald 1972, 1975). They formed the bases both for conservation laws and for the advances in mangrove research in other parts of the world. (Snedaker 1989). Research carried out ever since have provided sufficient insight into the range of ecological processes, functions and services of mangrove ecosystems (Table 1).

This work licensed under a Creative Commons Attribution-NonCommercial 4.0 International License 


\section{M.D. Amarasinghe}

Table 1 Major mangrove processes, functions, goods and services

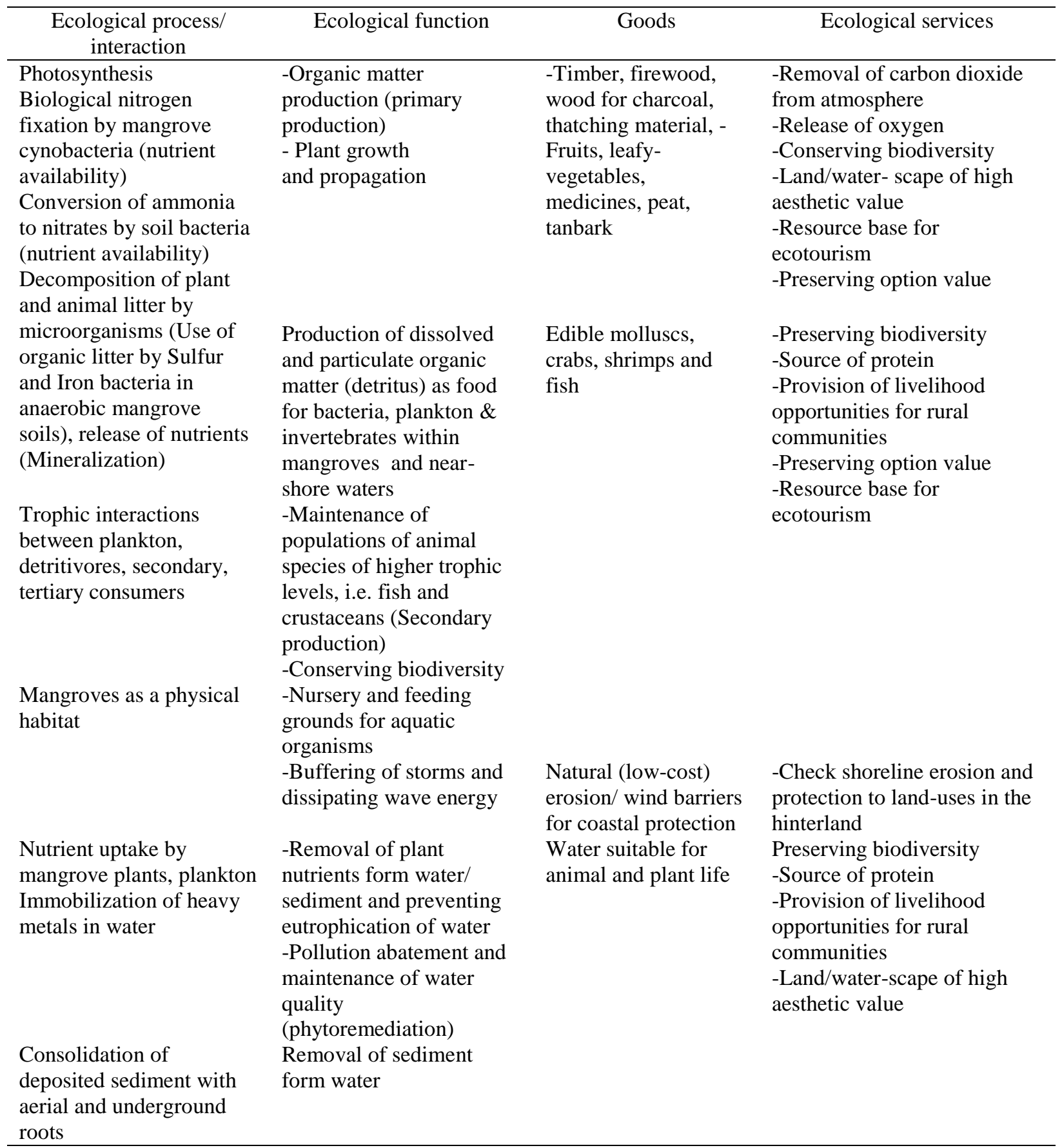


M.D. Amarasinghe

\section{INTER-TIDAL ZONE AND MANGROVE HABITATS}

Inter-tidal zone is defined as the coastal strip of land that is inundated with high tide and exposed during low tide, therefore this is an ecotone that lies between land and sea. Coasts may be either exposed to waves or they may be in a sheltere; d locality such as in an estuary or a lagoon which are not subjected to scourge of the waves and hence are relatively calm. Inter-tidal zones are found both in exposed and sheltered coasts including sandy beaches, rocky shores, bays, lagoons and estuaries.

Tidal amplitude and relief of the coastal areas will determine the extent of the inter-tidal zone as well as the tidal inundation pattern. Depending on the average tidal amplitude, coasts can either be macro-tidal $(>4 \mathrm{~m})$, micro-tidal $(<2 \mathrm{~m})$ or mesotidal $(2-4 \mathrm{~m})$. Due to relatively narrow continental shelf and the topography of the coastal terrain, Sri Lankan coasts are micro-tidal, where the maximum high tides do not exceed $1 \mathrm{~m}$. The high tide level varies with the time of the year (equinoctial high tides are greater than the normal high tides), weather and frequency of tides (diurnal, semi-diurnal or mixed). More land will be flooded during spring tides than during neap tides when the tidal amplitude is lowest. The exact boundaries of the inter-tidal zone therefore is not possible to determine only by short-term observations on tidal inundation, as the area flooded with tides vary throughout the year. This state of affairs have misled some to perceive that mangroves occur outside the inter-tidal zone.

\section{TRUE/ EXCLUSIVE MANGROVE AND PLANT SPECIES}

Identification of species endemic to the inter-tidal zone therefore is of paramount importance to demarcate the inter-tidal zones and mangrove areas for conservation management purposes. Inter-tidal zones support not only the mangrove species exclusive to inter-tidal areas (true mangroves) but also those that occur in adjacent terrestrial and freshwater ecosystems (mangrove associates), which are facultative halophytes that occur optionally, in response to circumstances rather than by nature.
A study on leaf structural traits and osmotic properties of plants in mangrove areas reveals that true mangroves are the true halophytes and mangrove associates are glycophytes with certain salt tolerance (Wang et al. 2010). Moreover, presence of non-exclusive species (mangrove associates) in the typical mangrove habitats indicates change, especially of salinity and inundation regimes. This highlights the importance of identification of plants as true and associate species in determining boundaries of the inter-tidal zone and therefore the mangrove areas. Generally this classification is based on observations on the occurrence of species within and outside the intertidal zones and it largely rests on how extensively the observations are made and how reliable the identification of plants is, thus, rendering a considerable element of subjectivity.

Mangrove species that are often subjected to controversy include Heritiera littoralis, Excoecaria agallocha, Xylocarpus granatum, and Acanthus ilicifolius. Based on leaf traits and leaf salt accumulation, Wang et al. (2010) classified $A$. ilicifolius, $X$. granatum and $P$. acidula as true mangroves while $H$. littoralis, E. agallocha and Acrostichum as associated species. Although Pemphis acidula is considered by most as a true mangrove species, it occurs on the cliff slopes, above the inter-tidal zone at Kudiramalai Point on the north western coast of Sri Lanka which receives sea-spray. Acrostichum aureum and A. speciosum, the only pteridophyte species in mangrove areas, are not exclusive to inter-tidal/mangrove areas, but associates, which also occur in brackish water and near-freshwater wetlands that are located away from inter-tidal areas.

In Sri Lanka, E. agallocha is often observed in the flood plain riparian forests in the upstream zones of estuaries in Sri Lanka, among typically freshwater species such as Terminalia arjuna (Kumbuk). E. agallocha however, forms monospecific stands like most true-mangrove species and are mostly found along the landward margin of mangrove stands. The total number of plants exclusively encountered in the inter-tidal zones is 24 with one hybrid species (Table 2). About 35 mangrove associated species are reported from Sri Lankan mangrove areas (Table 3) and their occurrence depends on the composition of the vegetation in the immediate supra-tidal areas. 


\section{MISCONCEPTIONS ON MANGROVE ECOLOGY AND THEIR IMPLICATIONS ON MANGROVE CONSERVATION AND MANAGEMENT}

\section{Mangroves occur outside the inter-tidal zone and they do not perform mangrove functions and services}

Ambiguity associated with identification of intertidal zone and therefore the mangrove habitats, emanates from the pseudo-scientific practice by some "scientists". Tidal inundation pattern cannot be comprehended with a single cursory observation and this is particularly true in a micro-tidal environment like the one prevails in Sri Lankan coasts. This would have misled some to perceive mangroves to be of two kinds, i.e., "terrestrial" mangroves (those that do not get flooded frequently) or those that occur outside the inter-tidal zone and mangroves which get inundated frequently and therefore the proper mangrove areas.

Table 2 List of true mangrove species reported from, or observed in Sri Lankan mangrove areas. (Amarasinghe and Perera 2017)

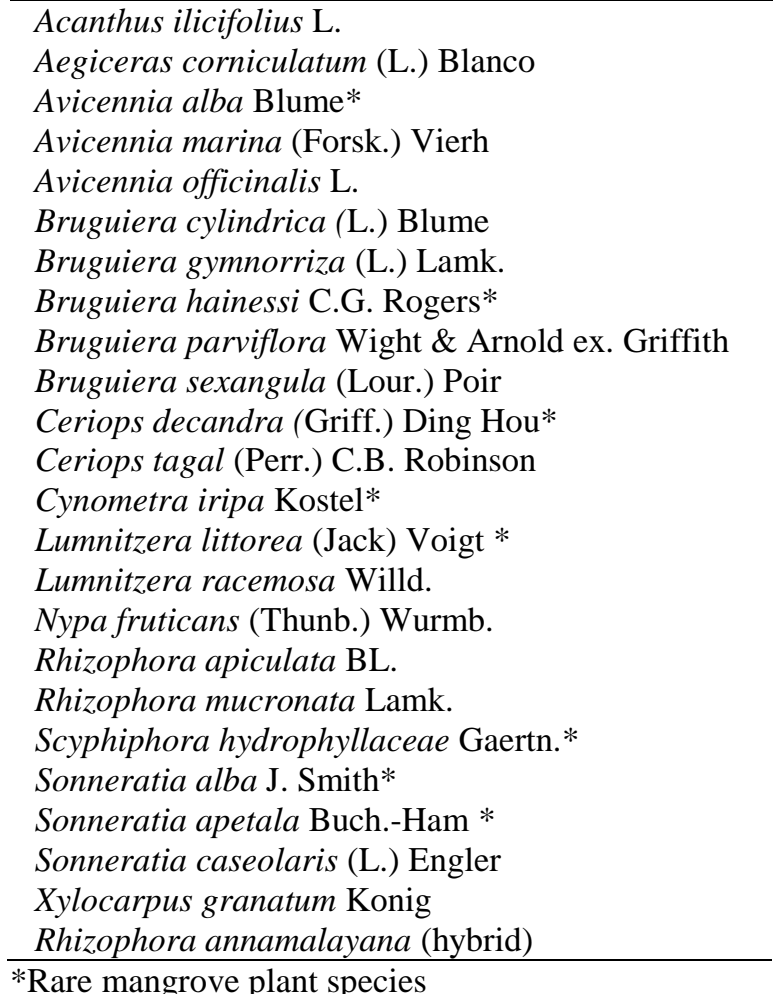

The "terrestrial" mangroves therefore are considered not worthy of protection and they can be sacrificed for economic development activities as their contribution to maintain coastal aquatic food webs and fishery production in these waters is marginal as the organic matter produced by them is not transported to coastal waters to support aquatic organisms. The management implication based on this pseudo-science is that infrequently flooded mangroves are worth converting to other land uses such as human settlements, urban expansion or even to shrimp ponds.

Moreover, inter-tidal areas associated with estuaries extend more inland as salt water penetrates along the rivers with rising tides and diminishing river flows, creating saline riverine zones. Often, tidal flow occurs along shallow creeks and depending on the terrain, salt water can be moved to considerable distances away from the sea/ lagoon/ estuary creating inter-tidal zones along the creek. All these inter-tidal areas or the land subjected to inundation with salt water can be colonized by halophytes, including mangroves. Cursory observations therefore lead to erroneous conclusion that mangroves occur outside the inter-tidal zone. The reality however is that under natural conditions, presence of mangroves is the most promising geographical indicator of boundaries of the intertidal zone. Altered local hydrological landscape by anthropogenic activities such as construction of roads and drainage canals too have extended the influence of sea water into more landward areas and has made them favourable for mangrove colonization and establishment. Presence of true mangrove species is the most reliable geographical indicator in demarcating the boundaries of intertidal zone as they are exclusive to it.

\section{Mangrove encroachment into open waters of Negombo estuary}

Mangroves have long been attributed to favour sedimentation of suspended soil particles during low tide and therefore contributes to land-building. Presence of pneumatphores have shown to facilitate sedimentation (Spenceley 1977). Species of Avicennia, with their pneumatophores have been observed to support sedimentation more than species of Rhizophora which have stilt and prop roots (Kathiresan 2003). Besides, amounts of 


\section{M.D. Amarasinghe}

sediment deposited within mangroves have shown to depend on the density of mangrove stems and roots (Kitheka et al. 2012).

Table 3 List of mangrove associated species recorded in mangrove areas of Sri Lanka (Amarasinghe and Perera 2017)

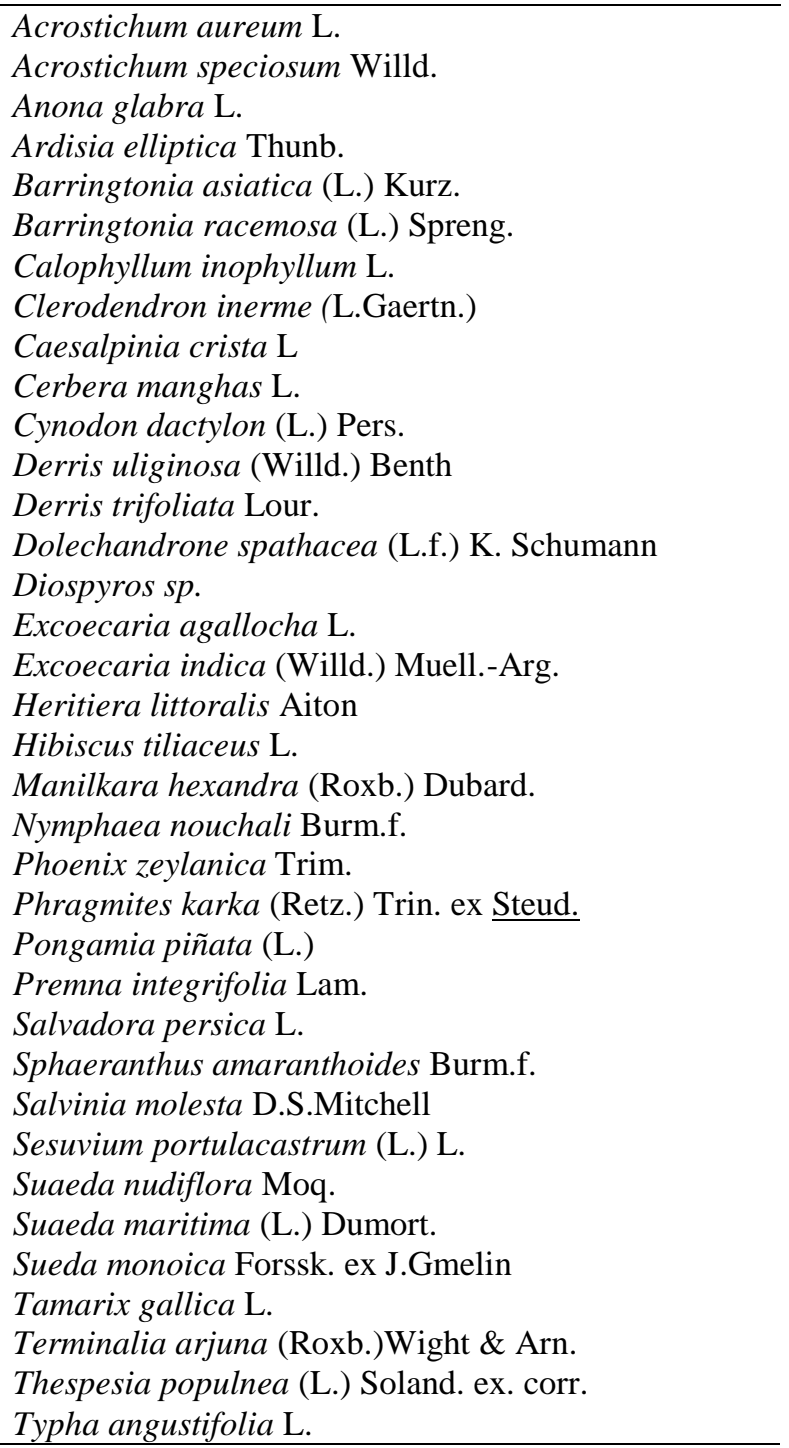

Lateral expansion of land due to presence of mangroves however is not substantiated and therefore is questionable. Evidence indicates that mangroves, once established, directly influence vertical land development by enhancing sedimentation and/or by direct organic contributions to soil volume (peat formation) in some settings, nevertheless, do not contribute to build up land (Lee et al. 2014).
The most plausible contribution by mangroves is the consolidation of sediment after its deposition through compaction of sediment as a result of absorption of water by the plants and holding soil/sediment thus resisting erosion by water (Augustin 1978). Extensive network of below ground roots too facilitates consolidation of sediment and therefore contribute to resist erosion by water. Diameter of the underground root system around a mangrove tree has been reported to be five times more than that of the canopy (Spenceley 1977). Mud flats in estuaries formed due to processes of flocculation and sedimentation may subsequently be colonized and developed into mangrove stands. Mangroves therefore contribute to consolidate already deposited soils as mud flats, rather than contributing for its sedimentation. Once established, mangroves may contribute to vertical but not lateral, accumulation of sediment and further contributes to consolidate the substratum of the mud flat. Mangroves therefore do not contribute to lateral expansion of land (land-building) that can subsequently be colonized by mangroves. Observations made by the author on mangroves in the northern part of Negombo estuary (Munnakkare, Wedikanda, Thaladuwa) that connects with Indian ocean since 1982, along with the information gathered from fishermen who grow mangroves to be extracted to construct brush parks (Amarasinghe 1988, Amarasinghe et al. 2001) substantiate this contention as all the man-made mangrove areas in Negombo estuary have established on mud flats, i.e. after the sedimentation has taken place. Human activities in the upstream of Dandugam Oya/ Attanagalu Oya and the immediate catchment of the estuary lead to discharge of increasing loads of sediment that eventually deposited in the estuary to form mud flats. Maximum flow velocities of most areas within Negombo estuary have found not to exceed $0.2 \mathrm{~m} / \mathrm{s}$ and this is well below the velocity, which, the sediment begins to move around (0.32 $\mathrm{m} / \mathrm{s}$ ) (Holms and Samarawickrema 1997), which means that most of the sediment that enters the estuary from the catchment does not leave the estuary. Besides, the tidal velocities of Negombo estuary are not high enough to generate a significant amount of sediment movement. Under such circumstances, even in the absence of any mangroves in the estuary, it will get silted up with time, disrupting fisheries and related livelihoods. 
In 2012 however, Samarakoon and Samarawickrema (2012) state that mangrove planting for livelihoods development results in diminished fish habitats, eventually resulting in the loss of fishery (secondary) productivity of the estuary due to siltation by mangroves and they attempt to substantiate their contention by highlighting a case study done in Segara Anakan Cilcap, Indonesia (Anon. 1992) as a lesson to be learnt and used as a warning. Though they state that fishery in this estuary has collapsed due to sediment entrapment, literature relevant to this study (Anon. 1992) reports otherwise. This represents intellectual dishonesty and manipulation of published information to support pseud-science based recommendations that proposes inappropriate solutions for environmental problems such as siltation. They further state that since restoration measures are prohibitively expensive, it is necessary to move away from belief-based good intentions (and traditional perceptions), i.e., protecting and planting mangroves, to science-based procedures, i.e. removal of mangroves, for ecosystem management (best practices). Removal of mangroves therefore is considered the sciencebased remedy for siltation and loss of habitats for estuarine organisms. Hydrology of Negombo estuary on the contrary, insinuates that sedimentation and loss of habitats may not be contained through removal of mangroves. Moreover, their attempt to support their contention by highlighting the case study from Segara Anakan estuary in central Java Indonesia (Anon. 1992) becomes a failure as Indonesian scientists propose to protect 4600 ha of mangroves in this estuary, as a reserve. The Citanduy river that supplies about $95 \%$ of water flowing into the estuary drains the 350,000 ha Citanduy Basin. Land use within this catchment, especially, agriculture, therefore has been identified to cause significant impact on Segara Anakan estuary through erosion, sediment transport and deposition. The average amount of suspended solids discharged into the estuary was reported to be as high as $700 \mathrm{mg} \mathrm{l}^{-1}$. Flushing of Segara Anakan estuary is primarily driven by tidal action and is limited by the small size of entrances at the east and west ends of the estuary. This hydrological regime allows a high percentage of suspended sediments to settle in the estuary and it has consequently led to reduce the estuarine depth to $1.48 \mathrm{~m}$ (Anon. 1992).
Sedimentary processes in Segara Anakan estuary in Indonesia therefore provides an ideal analogy for that in Negombo estuary. While distorting the lesson emerging with sedimentation issues of Segara Anakan estuary, inappropriate remedial measures have been proposed for Negombo estuary, based on pseudo- science related to mangrove ecology, Indonesian scientists propose to train farmers in the upstream areas of Segara Anakan estuary in sustainable farming techniques that minimize soil erosion, which they consider more pragmatic and effective in controlling siltation in the long term, than dredging or removing mangroves from the estuary. Moreover, they propose to protect 4,602 ha of mangrove forest as a reserve (Anon. 1992). Hegemony of pseudoscientists in the arena of environmental management is a poorly discussed issue in public domain, nevertheless, is a noteworthy concern that affects pragmatic and sustainable decision-making to solve environmental problems.

\section{REFERENCES}

Amarasinghe, M.D. 1988. Socio-economic status of human communities of selected mangrove areas on the west coast of Sri Lanka. Mangrove Ecosystem Occasionally Papers No. 3. UNDP/UNESCO Regional Mangrove Project, UNESCO, Paris.

Amarasinghe, M.D. and K.A.R.S. Perera 2017. Historical biogeography of mangroves in Sri Lanka. Ceylon Journal of Science 46 (Special Issue) 2017: 111-117.

DOI: http://doi.org/10.4038/cjs.v46i5.7458

Amarasinghe, U.S., M.D. Amarasinghe and C. Nissanka 2002. Investigation of the Negombo estuary (Sri Lanka) brush park fishery, with an emphasis on community-based management. Fisheries Management and Ecology 9: 41-56.

DOI: 10.1046/j.1365-2400.2002.00250.x

Anon. 1992. The integrated management plan for Segara Anakan-Cilacap, Central Java, Indonesia. ASEAN/US Coastal Resources Management Project. International Center for Living Aquatic Resources Management, Manila. Technical Report No. 34. 100 p.

Augustinus, P.G.E.F. 1995. Geomorphology and sedimentology of mangroves. Developments in Sedimentology 53: 333-357. 
https://doi.org/10.1016/S0070-4571(05)80032-9 Bouillon, S., A.V. Borges, E. Castañeda-Moya, K. Diele, T. Dittmar, N.C. Duke, E. Kristensen, S.Y. Lee, M. Marchand, J.J. Middelburg, V.H. Rivera-Monroy, T.J. Smith and R.R. Twilley 2008. Mangrove production and carbon sinks: A revision of global budget estimates. Global Biogeochemical Cycles 22: GB2013. DOI: 10.1029/2007GB003052

Holms, P. and S.P. Samarawickrama 1997. Numerical modelling of sediment transportation in the Negombo Lagoon, Sri Lanka. Journal of Institution of Civil Engineers, Sri Lanka, June 197: $10-21$

Kitheka, J.U., G.S. Ongwenyi and K.M. Mauti 2012. Dynamics of suspended sediment exchange in a degraded mangrove creek in Kenya. Ambio 31 (7-8): 580 - 587.

Lee, S.Y., J.H. Primavera, F. Dahdouh-Guebas, K. McKee, J.O. Bosire, S. Cannicci, K. Diele, F. Fromard, N. Koedam, C. Marchand, I. Mendelssohn, N. Mukherjee and S. Record 2014. Ecological role and services of tropical mangrove ecosystems: a reassessment. Global Ecology and Biogeography 23(7): 726-743. DOI: $10.1111 /$ geb.12155

Nagelkerken, I., S.J.M. Blaber, S. Buillon, P. Green., M. Heywood, L.G. Kirton, J.O. Meynecke, J. Pawlik, H.M. Penrose, A. Sasekumar and P.J. Somerfield 2008. The habitat function of mangroves for terrestrial and marine fauna: A review. Aquatic Botany 89 (2): 155-185.

https://doi.org/10.1016/j.aquabot.2007.12.007

Odum, W.E. and E.J. Heald 1972. Trophic analyses of an estuarine mangrove community. Bulletin of Marine Science 22 (3): 671-738. DOI: 10.12691/marine-2-1-3

Odum, W.E. and E.J. Heald, 1975. The detritusbased food web of an estuarine mangrove community. pp. 265-286. In: L.E. Cronin (ed.) Estuarine Research. Academic Press, New York Samarakoon, J. and S. Samarawickrama 2012. An appraisal of challenges in the sustainable management of the micro-tidal barrier-built estuaries and lagoons in Sri Lanka. IUCN Sri Lanka Country Office, Colombo. 171p.

Snedaker, S.C. 1989. Overview of ecology of mangroves and information needs for Florida Bay. Bulletin of Marine Science 44(1): 341-347.
Spenceley, A.B. 1977. The role of pneumatophores in sedimentary process. Marine Geology 24: M31-M37. https://doi.org/10.1016/0025-3227(77)90001-9

Wang, L., M. Mu, X. Li, P. Lin and W. Wang. 2010. Differentiation between true mangroves and mangrove associates based on leaf traits and salt contents. Journal of Plant Ecology 4(4): 292301. DOI:10.1093/jpe/rtq008 